\title{
各種 $\mathrm{Si}_{3} \mathrm{~N}_{4}$ セラミックスの被研削加工特性
}

\author{
西岡隆夫・田中芳雄* \\ 住友電気工業(株) 伊丹研究所, 664 兵庫県伊丹市昆陽北 1-1-1 \\ *大阪府立大学機械システム工学科, 593 大阪府堺市学園町 1-1
}

\author{
Grindability of Various Silicon Nitride Ceramics \\ Takao NISHIOKA, Yoshio TANAKA*, Akira YAMAKAWA and Masaya MIYAKE \\ Itami Research Laboratories, Sumitomo Electric Industries, Ltd., 1-1-1, Koya-Kita, Itami-shi, Hyogo 664 \\ *Department of Mechanical Systems Engineering, Osaka Prefecture University, 1-1, Gakuen-cho, Sakai-shi, Osaka 593
}

\begin{abstract}
The grindability of various silicon nitride ceramics ground using different diamond grinding wheels was evaluated in terms of specific grinding energy and strength degradation. Main results are summarized below. (1) Specific grinding energy increases with increasing hardness of the workpiece material using a grinding wheel of small grain size under the condition of small wheel depth of cut. (2) Strength degradation increases with a grinding wheel of large grain size. Degradation increases with a smaller material constant of the critical indentation radius : $E \cdot K_{\mathrm{c}}{ }^{2} / \boldsymbol{H}_{\mathrm{v}}{ }^{3}$ (E: Young's modulus, $K_{1 \mathrm{c}}$ : fracture toughness, $H_{\mathrm{v}}$ : Vickers hardness). (3) The degradation increases with increasing mean value of maximum grain depth of cut. The strength in the region of a large mean value of maximum grain depth of cut decreases with a larger material constant of crack extension length : $H_{\mathrm{v}}^{1 / 4} / K_{\mathrm{c}}$.
\end{abstract}

[Received June 1, 1995; Accepted September 14, 1995]

Key-words : Silicon nitride ceramics, Specific grinding energy, Strength degradation, Maximum grain depth of cut, Critical indentation radius, Crack extension length

\section{1. 緒 言}

$\mathrm{Si}_{3} \mathrm{~N}_{4}$ セラミックスは耐熱性，耐摩耗性，高剛性等の優 れた特性をもち，構造材料としての期待が大きい材料であ る. $\mathrm{Si}_{3} \mathrm{~N}_{4}$ セラミックスを構造材料として用いる場合, 焼 結体の寸法精度が不十分であり，2 次的な機械加工が行わ れるが，ダイヤモンド砥石による研削加工は加工精度，加 工能率に優れ，最も重要な加工方法である。

一方，近年 $\mathrm{Si}_{3} \mathrm{~N}_{4}$ セラミックスは工業的な実用化を目的 とし， $\mathrm{Si}_{3} \mathrm{~N}_{4}$ 及びサイアロン結晶相の複合化や結晶粒径の 制御により著しく特性の向上が図られており1) 3)，その 被研削特性に関する研究がこれらのセラミックスを応用す るうえで重要と考えられる.

セラミックスの被研削特性に関する研究はこれまでも多 くなされており，ジルコニアやアルミナなどのセラミック ス2),5) や，またここで取り上げる $\mathrm{Si}_{3} \mathrm{~N}_{4}$ セラミックスでも 常圧焼結を行った比較的機械的特性の低い材料(6),7)などが 対象となっている。しかしながらこれらの報告ではそれぞ れの材料について，研削条件を変えたときの研削抵抗や比 研削エネルギーの変化に関する実験的な検討が主として行 われて抢り，材料の微細構造や物性值の差異が被研削特性 に及ぼす影響を統一的に検討した例は少ない。

本報では，結晶相や結晶粒径を変化させた種々の $\mathrm{Si}_{3} \mathrm{~N}_{4}$ セラミックスを各種ダイヤモンド砥石により平面研削加工 した場合の比研削エネルギーや加工後の強度劣化を評価し た。 なたれらの被研削特性について，砥粒が作用した際 に材料内にき裂が進展する程度を表す材料パラメーターを 用いて考察した. 更にこの材料パラメーターと加工後の強
度劣化が顕著になる際の臨界の最大砥粒切込み深さを関係 づけることにより，各材料に対して強度劣化を抑える研削 条件を推定する手法を提案した.

\section{2. 実験方法}

\section{1 各種 $\mathrm{Si}_{3} \mathrm{~N}_{4}$ セラミックスの作製と評価}

窒化ケイ素セラミックスの作製には，原料粉末として宇 部興産製 $\mathrm{Si}_{3} \mathrm{~N}_{4}$ 粉末 $\mathrm{E} 10$ グレード（平均粒径 $0.63 \mu \mathrm{m}$, 酸 素量 1.45 mass \% , $\alpha$ 率96.5\%）と，焼結助剤として住友化 学工業製 $\mathrm{Al}_{2} \mathrm{O}_{3}$ 粉末 $\mathrm{AKP}-30$ グレード，信越化学工業製

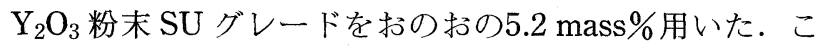
の粉末をエタノール中にて $72 \mathrm{~h}$ ボールミル混合し乾燥した 後, 冷間静水圧プレス (CIP) 成形 (圧力 $150 \mathrm{MPa}$ ) した. 得られた成形体より $8 \mathrm{~mm} \times 6 \mathrm{~mm} \times 50 \mathrm{~mm}$ の予備成形体 を切り出し, $1650 \sim 1850^{\circ} \mathrm{C}, 4 \mathrm{~h}, 0.4 \mathrm{MPa}$ の $\mathrm{N}_{2}$ ガス雾囲 気で 1 次焼結した後, 一部の 1 次焼結体は更に $1650^{\circ} \mathrm{C}$, $1 \mathrm{~h}, 100 \mathrm{MPa}$ の $\mathrm{N}_{2}$ ガス雾囲気で熱間静水圧プレス (HIP) 処理した.

2.2節で述べる実験に用いた研削加工材（以下，これを 強度劣化のみられない試験片として平滑材と呼ぶ）は以下 の方法で作製した。すなわち上述で得られた焼結体を粒度 \#200のレジンボンド砥石を用い，砥石の設定切込み量 $3 \mu \mathrm{m}$, テーブル速度 $20 \mathrm{~m} / \mathrm{min}$, トラバース送り量 500 $\mu \mathrm{m} /$ トラバース, スパークアウト研削 5 往復の条件で, 加工材の長手方向に研削加工した後, 粒度＃1500のダイ ヤモンドペーストにより JIS R1601準拠の試験片に表面仕 上げした。 
各 $\mathrm{Si}_{3} \mathrm{~N}_{4}$ セラミックスの機械的特性は次の方法で評価し た。すなわち，曲げ強度は上述の平滑材のエッジ部に JIS 規定の $R$ 面取り加工を施した試験片について JIS R1601 に準拠した 3 点曲げ強度試験を，破壊勒性 $\left(K_{1 \mathrm{c}}\right)$ は JIS R1607に準拠した SEPB 試験を，ヤング率は JIS R1601 準拠の試験片を用いた曲げ共振法8)を，硬度は荷重300 g のマイクロビッカース硬度試験をそれぞれ用いて評価し た。これらにより得られた焼結体の特性を表 1 に示す。表 1 において各材料は $\mathrm{Si}_{3} \mathrm{~N}_{4}-\mathrm{B}$ を基準とし，これに比べ焼結 温度を低下させ結晶粒径を小さくしたものが $\mathrm{Si}_{3} \mathrm{~N}_{4}-\mathrm{A}$ ，焼 結温度を上昇させ結晶粒径を大きくしたものが $\mathrm{Si}_{3} \mathrm{~N}_{4}-\mathrm{C}$, また以上と異なり HIP 処理を施さなかったものが $\mathrm{Si}_{3} \mathrm{~N}_{4}$ Dである。

\section{2 平面研削実験方法}

本実験には，研削盤としてナガセインテグレックス製平 面研削盤 SGM-52E2 を，研削動力計はキスラー製9257B 及び，チャージアンプにはキスラー製5019A130をそれぞ れ用いた。

表 2 には，本実験に用いた 4 種類のダイヤモンド砥石 を示す．用いた砥石は粒度を変化させた 3 種のレジンボ ンド砥石と 1 種のメタルボンド砥石である.

一方，実験に用いた研削加工条件を表 3 に示す。研削実 験は，各砥石を一定のツルーイング，ドレッシング条件に より整形した後，テーブル上に固定した研削動力計の上に
工作物を取り付け，上向き研削（砥石の回転方向と工作物 の送り方向が逆方向の研削）でワンパスだけ砥石を送ると いう方式で行った ${ }^{9)}$ 。ここで研削条痕の方向は，研削によ る材料の強度劣化に及ぼす影響が顕著に評価できるよう に，曲げ強度試験片の長手方向に対し直角方向に設定し た ${ }^{9}$ ．また，比研削エネルギー $U_{\mathrm{e}}$ (単位砥石幅当たり単 位体積の工作物を除去するのに必要なエネルギー)，の算出 で用いる工作物の除去断面積は，研削条痕断面を触針式表 面粗さ計で測定した断面形状より直接求めた．この断面積 $S$ を用いて比研削エネルギーは次式により算出した。

$$
U_{\mathrm{e}}=\left(F_{\mathrm{h}} \cdot V\right) /(S \cdot v)
$$

ここで, $F_{\mathrm{h}}$ : 研削抵抗の水平成分, $V$ : 砥石周速

$$
v \text { : テーブル速度 }
$$

研削試料の強度評価は，試料のエッジ部を JIS 規定の $R$ 面取りを施した試験片について，研削部を引張り面とした JIS R1601準拠の 3 点曲げ強度試験（試験本数は 1 条件に つき10本とした）を用いて行った。

\section{3. 実験結果及び考察}

\section{1 各種 $\mathrm{Si}_{3} \mathrm{~N}_{4}$ セラミックスの比研削エネルギー}

図 1 (a), (b)に 4 種類の $\mathrm{Si}_{3} \mathrm{~N}_{4}$ セラミックスについて, テーブル速度を変えたときの比研削エネルギーの変化を示 した.
Table 1. Characteristics of Workpiece Materials

\begin{tabular}{|l|c|c|c|c|}
\hline \multicolumn{1}{|c|}{ Material } & $\mathrm{Si}_{3} \mathrm{~N}_{4}-\mathrm{A}$ & $\mathrm{Si}_{3} \mathrm{~N}_{4}-\mathrm{B}$ & $\mathrm{Si}_{3} \mathrm{~N}_{4}-\mathrm{C}$ & $\mathrm{Si}_{3} \mathrm{~N}_{4}-\mathrm{D}$ \\
\hline Post sintering & $\mathrm{HIP}$ & $\mathrm{HIP}$ & $\mathrm{HIP}$ & Non-HIP \\
\hline Density $\left(\times 10^{3} \mathrm{~kg} / \mathrm{m}^{3}\right)$ & 3.25 & 3.24 & 3.24 & 3.21 \\
\hline Mean grain size $(\mu \mathrm{m})$ & 0.25 & 0.53 & 0.92 & 0.50 \\
\hline Crystalline phase $*$ & $\alpha, \beta$ & $\beta$ & $\beta$ & $\beta$ \\
\hline 3-point bending strength $(\mathrm{MPa})$ & 1620 & 1220 & 970 & 860 \\
\hline Young's modulus (GPa) & 310 & 295 & 270 & 265 \\
\hline Vickers hardness (GPa) & 17.5 & 15.2 & 14.4 & 13.8 \\
\hline Fracture toughness $\mathrm{MPa} \cdot \sqrt{\mathrm{m})}$ & 5.2 & 5.4 & 6.8 & 5.0 \\
\hline
\end{tabular}

$* \alpha: \alpha-\mathrm{Si}_{3} \mathrm{~N}_{4}, \beta: \beta-\mathrm{Si}_{3} \mathrm{~N}_{4}$

Table 2. The Type of Grinding Wheel for Test

\begin{tabular}{|l|l|}
\hline 1) Resinoid-bonded wheel & $\begin{array}{l}\text { - SD100,75 (Grain : EBG made by General Electric) } \\
\text { - Grain size : } \# 100(125-150 \mu \mathrm{m}), \# 325(37-45 \mu \mathrm{m}) \\
\# 800(12-25 \mu \mathrm{m})\end{array}$ \\
& $\begin{array}{l}\text { Diameter of wheel : } 200 \mathrm{~mm} \\
\text { 2) Metal-bonded wheel }\end{array}$ \\
\hline $\begin{array}{l}\text { SD100,75 (Grain : MBG-660T made by General Electric) } \\
\text { Grain size : \#100 } \\
\text { - Diameter of wheel : } 200 \mathrm{~mm}\end{array}$ \\
\hline
\end{tabular}

Table 3. The Conditions of Truing, Dressing and Test Grinding

\begin{tabular}{|l|c|c|c|c|c|}
\hline Process & $\begin{array}{c}\text { Wheel speed } \\
(\mathrm{m} / \mathrm{min})\end{array}$ & $\begin{array}{c}\text { Table speed } \\
(\mathrm{m} / \mathrm{min})\end{array}$ & $\begin{array}{c}\text { Wheel depth } \\
\text { of cut }(\mu \mathrm{m})\end{array}$ & $\begin{array}{c}\text { Traverse rate } \\
(\mathrm{m} / \mathrm{pass})\end{array}$ & $\begin{array}{l}\text { Wheel of truing } \\
\text { and dressing }\end{array}$ \\
\hline Truing & 650 & 10 & 20 & 1.0 & GC\#200-\#450 \\
\hline Dressing & 950 & 10 & 10 & 1.0 & WA\#220-\#600 \\
\hline Test & 1890 & 4.12 .20 & $3,6.5,10$ & - & - \\
\hline
\end{tabular}
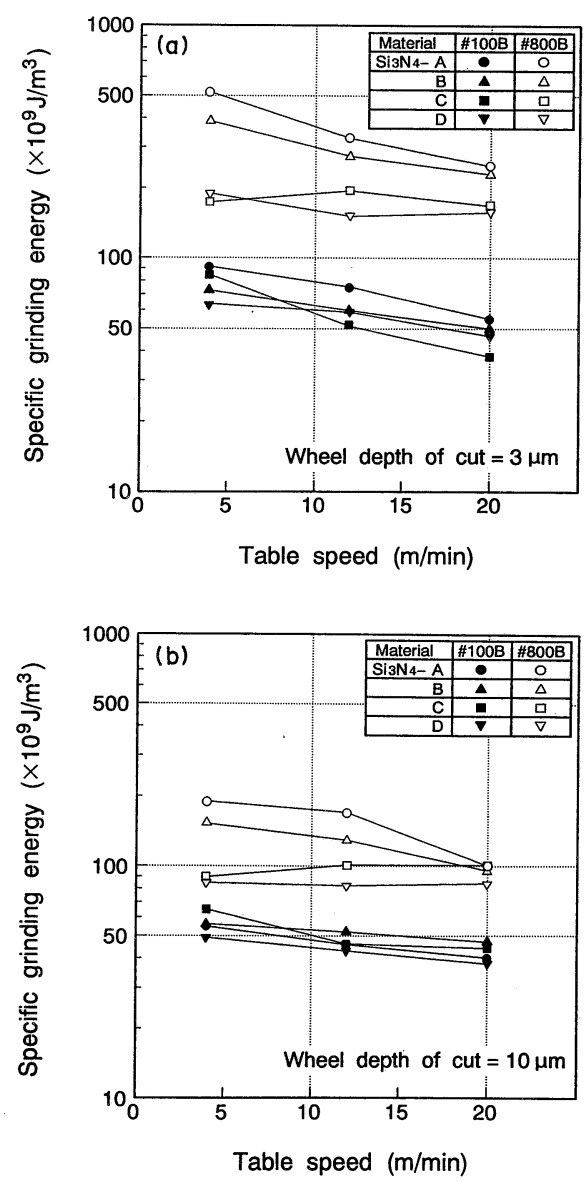

Fig. 1. The relationship between specific grinding energy and table speed. 
図 1 の結果から，いずれの材料も砥石設定切込久量の 増加に対し比研削エネルギーが低下することが分かり，特 にこの傾向は砥粒径の小さい，\#800レジンボンド砥石を 用いた場合にやや顕著であることが分かる．また\#100レ ジンボンド砥石に比べ８00レジンボンド砥石を用いた場 合の方が高い比研削エネルギーをもつことが分かる.すな わち, \#800レジンボンド砥石を用いた場合及び砥石設定 切込み量が小さい場合に, 最大砥粒切込久深さが小さくな り，これにより塑性流動的な材料除去の占める割合が大き くなって比研削エネルギーが増大したものと考えられ $ろ^{9), 10)}$.

各材料の比研削エネルギーは，砥石設定切込み量が小さ い場合 $(3 \mu \mathrm{m})$ 及び＃800レジンボンド砥石を用いた場合 に, $\mathrm{Si}_{3} \mathrm{~N}_{4}-\mathrm{A}>\mathrm{B}>\mathrm{C}, \mathrm{D}$ の順に顕著に小さくなることが分 かる.すなわち，最大砥粒切込み深さが小さい領域では塑 性流動的な材料除去が主となり，この領域での比研削エネ ルギーは硬度が高いほど大きな比研削エネルギーをもつと 考えられる. したがって表 1 に示した硬度の高い材料か ら順に比研削エネルギーが小さくなるものと考えられる.

\section{2 各種 $\mathrm{Si}_{3} \mathrm{~N}_{4}$ セラミックスの加工後の強度変化}

図 2 (a), (b)に 4 種類の $\mathrm{Si}_{3} \mathrm{~N}_{4}$ セラミックスについて, 砥石設定切込久量を変えたときの加工後の材料強度の変化 を示した。
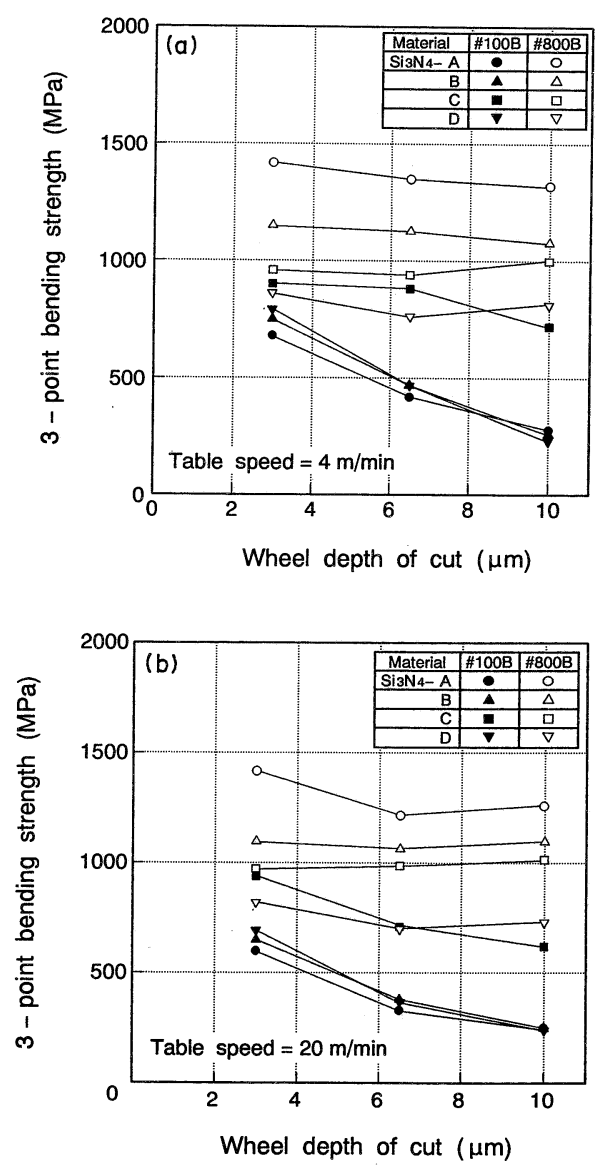

Fig. 2. The relationship between 3-point bending strength and wheel depth of cut.
図 2 の結果から，いずれの材料も粒径の小さい\#800レ ジンボンド砥石を用いた方が加工後の強度が高く，また砥 石設定切込みの増加に対して強度の变化が小さいことが分 かる. 特にテーブル速度が $4 \mathrm{~m} / \mathrm{min}$ の場合には，各砥石 設定切达み量に対し，ほぼ表 1 に示した平滑材に相当す る強度をもつことが分かる。これは上述したように，\# 800レジンボンド砥石を用いた場合，最大砥粒切込み深さ が小さくなり，そのために加工表面におけるき裂等の欠陥 の生成が抑制されたことによるものと考えられる10).

\section{3 最大砥粒切込み深さと加工後の強度変化}

ここでは, 上述の加工後の工作物の強度変化に及ぼす最 大砥粒切込及深さの影響が大きいものと考え，既報9),10)で 示した手法により, 砥石周速やテーブル速度の増大による 最大砥粒切込み深さの変化を解析し考察を行った.なお， 最大砥粒切込み深さの解析には, 砥石作業面の砥粒切刃の 分布を考慮した統計的解析手法を適用し，その平均值（以 下平均砥粒切込久深さと呼ぶ）を数值解析した：この数值 解析に用いた各ダイヤモンド砥石の連続切刃間隔は既 報10)の手法により求めた以下の近似式を用いた。

レジンボンド\#100砥石 $: a(\delta)=2210 \cdot \exp (-0.20 \delta)$

レジンボンド\# 325 砥石 : $a(\delta)=450 \cdot \exp (-0.54 \delta)$

レジンボンド\# 800 砥石 : $a(\delta)=185 \cdot \exp (-0.68 \delta)$

メタルボンド\# 100 砥石 : $a(\delta)=895 \cdot \exp (-0.29 \delta)$

ここで, $a(\delta):$ 連続切刃間隔 $(\mathrm{mm})$

$\delta:$ 砥石表面よりの半径深さ $(\mu \mathrm{m})$

一方, 平均砥粒切込久深さの数值解析に用い万砥石結合 材と工作物の剛性の值も既報10)で示した手法により計測 し，その結果を表 4 に示した。

図 3 (a)〜 (c) には $\mathrm{Si}_{3} \mathrm{~N}_{4}$-B を基準として他の 3 材料に ついて, 数值解析した平均砥粒切込久深さと加工後の材料 強度の関係を示す9)。

図 3 の結果から，各材料ともに平均砥粒切込み深さの 増大につれて強度が低下することが分かる。 また $\mathrm{Si}_{3} \mathrm{~N}_{4}$ $\mathrm{B}$ に比べて $\mathrm{Si}_{3} \mathrm{~N}_{4}-\mathrm{A}$ は小さい平均砥粒切込み深さの領域 で, また $\mathrm{Si}_{3} \mathrm{~N}_{4}-\mathrm{C}$ は大きい平均砥粒切込み深さの領域で 強度が低下している。 一方, 平均砥粒切込み深さが $1 \mu \mathrm{m}$ 以上の領域では, $\mathrm{Si}_{3} \mathrm{~N}_{4}-\mathrm{C}$ 以外の 3 種類の材料はほぼ同等 の強度をもつことが分かる. 以上の各材料の加工後の強度 変化については3.4節で詳細な考察を加える.

\section{4 各種 $\mathrm{Si}_{3} \mathrm{~N}_{4}$ セラミックスの材料特性と被研削特性}

Table 4. Rigidity of Wheel Bond and Workpiece Material

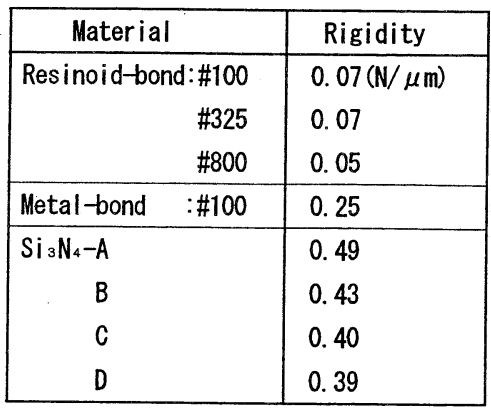



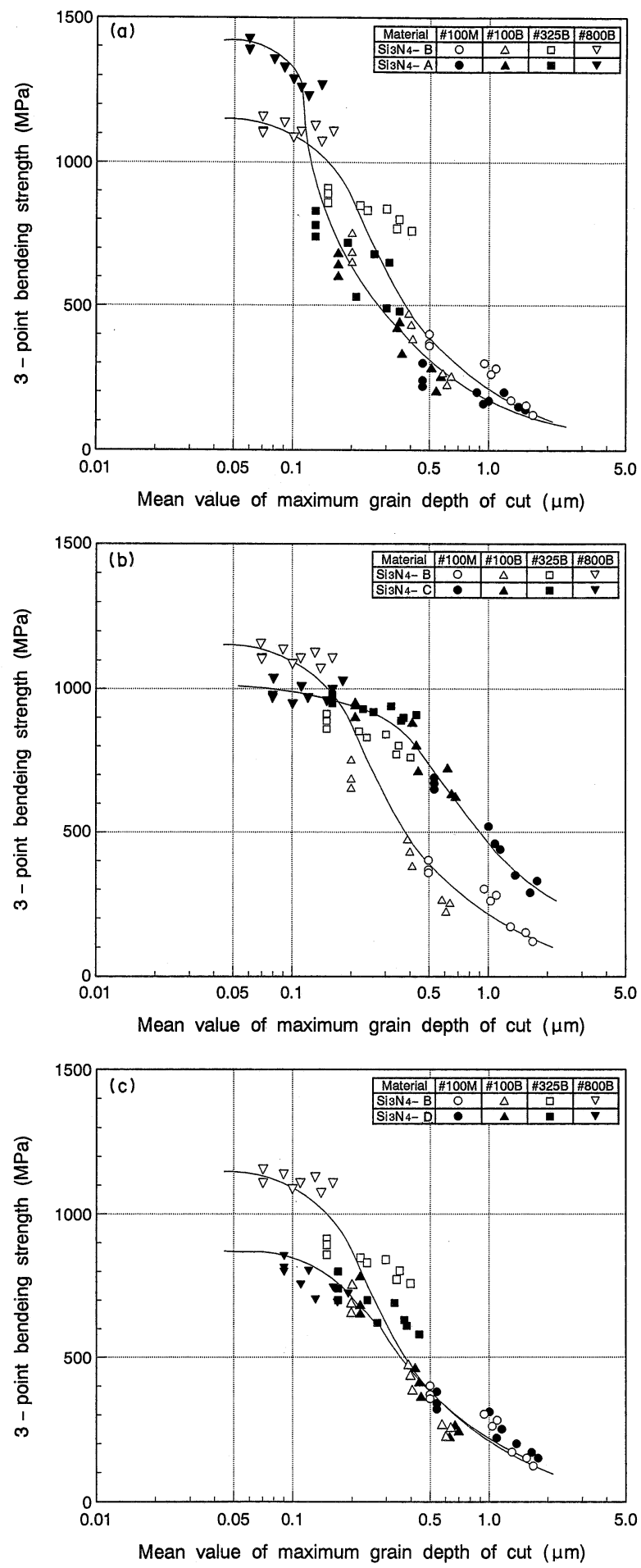

Fig. 3. The relationship between 3-point bending strength and mean value of maximum grain depth of cut.

ここでは 3.2 節及び, 3.3 節で述べてきた加工後の材料 強度の変化を各 $\mathrm{Si}_{3} \mathrm{~N}_{4}$ セラミックスの機械的特性との関係 から考察する.

ここで各材料に砥粒が作用した際に，材料内に発生する き裂進展が材料強度の变化に及ぼす影響が大きいと考えら れるため，砥粒先端が球状の圧子であると仮定し，この圧 子が各材料を引っかいた際のき裂進展における遷移圧子半 径（この值以下の半径をもつ圧子を用いた場合には，圧子
押し込み時に少なくとも弾性変形状態ではき裂が進展しな い臨界の半径）と十分塑性域が発達した後に発生するき裂 の進展長さを用いて，研削された材料の強度劣化特性を調 べる ${ }^{11)}$ 。このときの影響因子としての材料特性項には次 式を用いた ${ }^{11)}$.

遷移圧子半径 : $E \cdot K_{\mathrm{c}}{ }^{2} / H_{\mathrm{v}}{ }^{3}\left(\times 10^{-6} \mathrm{~m}\right)$

き裂進展長さ : $H_{\mathrm{V}}^{1 / 4} / K_{\mathrm{c}}\left(\times 10^{-4} \mathrm{~m} / \mathrm{N}^{3 / 4}\right)$

ここで, $E$ : 材料のヤング率, $H_{\mathrm{v}}$ : 材料のビッカース硬 度, $K_{\mathrm{c}}$ は表 1 に示す $K_{1 \mathrm{c}}$ の值を用いる

表 5 に各 $\mathrm{Si}_{3} \mathrm{~N}_{4}$ セラミックスの材料特性項の值を示す. ここで表 5 で示した材料特性項を用い加工後の材料の強 度変化を考察する．まず四 3 で示した平均砥粒切込久深 さが $1 \mu \mathrm{m}$ 以上の領域では, 加工の際に発生するき裂が十 分進展した領域と考えられるため, 表 5 に示すき裂進展 長さに関する材料特性項がほぼ同等である $\mathrm{Si}_{3} \mathrm{~N}_{4}-\mathrm{A}, \mathrm{B}, \mathrm{D}$ が同レベルの加工後の材料強度を示したと考えられる。一 方, き裂進展長さに関する材料特性項が他の 3 材料に比 べ小さい $\mathrm{Si}_{3} \mathrm{~N}_{4}-\mathrm{C}$ は加工後のき裂進展長さが小さく, 高 い加工後の材料強度を示したと考えられる.

更に, 図 3 で示した各材料の顕著な加工後の強度劣化 が始をる平均砥粒切込久深さを臨界砥粒切込及深さと定義 し，図中より読久取ったこの值と材料特性項のうち遷移圧 子半径との関係を図 4 に示した。この結果から両者はよい 線形関係にあることが分かる.

本実験に用いた砥石及び加工条件では, 特に碰粒径の大 きい砥石（\#100）を用いた場合，砥粒の平均粒径に対し 平均砥粒切込久深さが極めて小さいため, 加工中の砥粒/ 工作物の接触領域で十分な塑性領域が発達する以前に弾性 域でき裂が発生しているものと考えられる。ここで，遷移 圧子半径は圧子押し込久時の弾性域でのき裂進展と塑性開 始の難易を表す指標の一つであり，この值が小さいほどき

Table 5. Material Constants

\begin{tabular}{|l|c|c|c|c|}
\hline \multicolumn{1}{|c|}{ Mater ial constant } & $\mathrm{Si}_{3} \mathrm{~N}_{4}-\mathrm{A}$ & $\mathrm{Si}_{3} \mathrm{~N}_{4}-\mathrm{B}$ & $\mathrm{Si}_{3} \mathrm{~N}_{4}-\mathrm{C}$ & $\mathrm{Si}_{3} \mathrm{~N}_{4}-\mathrm{D}$ \\
\hline $\mathrm{E} \cdot \mathrm{K}_{\mathrm{c}}{ }^{2} / \mathrm{H}_{\mathrm{v}}{ }^{3}\left(\times 10^{-6} \mathrm{~m}\right)$ & 1.56 & 2.45 & 4.18 & 2.52 \\
\hline $\mathrm{H}_{\mathrm{v}}{ }^{1 / 4} / \mathrm{K}_{1}\left(\times 10^{-4} \mathrm{~m} / \mathrm{N}^{3 / 4}\right)$ & 2.21 & 2.06 & 1.61 & 2.16 \\
\hline
\end{tabular}

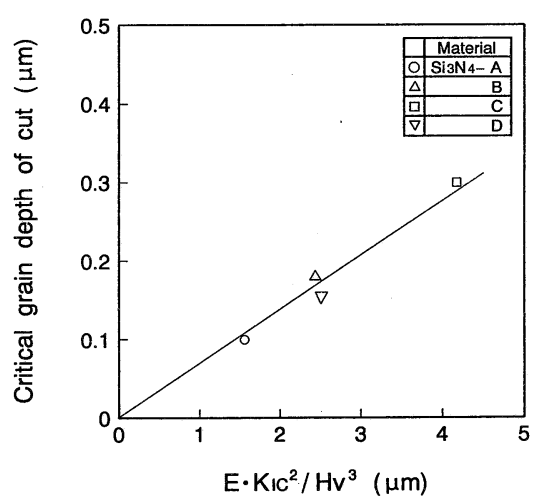

Fig. 4. The relationship between material constant : $E \cdot K_{1 \mathrm{c}}{ }^{2} / H_{\mathrm{v}}{ }^{3}$ and mean value of maximum grain depth of cut

$E$ : Young's modulus of workpiece, $K_{1 \mathrm{c}}$ : Fracture toughness of workpiece, $H_{\mathrm{v}}$ : Vickers hardness of workpiece. 
裂進展が容易に起こり，塑性変形が生じ難いことを示して いる．一方，圧子押し込及時の弾性変形状態での応力場の 強さは，弾性論によれば圧子押し込み深さと圧子径の比に 比例する11). したがって遷移圧子半径が大きい材料では 押し込み量が大きくなければ，き裂が進展し難いと考えら れるので，強度劣化を加速する押し达み量（ここでは臨界 碈粒切込み深さに相当する）と遷移圧子半径とは密接な関 係があることは容易に推定できることである.

以上より，本実験の範囲に扔いては，被加工材料が決ま れば，その機械的特性から材料特性項で表した遷移圧子半 径を算出し，更に図 4 の関係を用いて臨界砥粒切込み深 さを求めることにより，この臨界砥粒切込久深さに対応す る加工後の材料強度の低下が少ない研削条件（砥石種, 設 定加工条件）を推定することが可能であると考えられる。

\section{4. 結 言}

結晶相や結晶粒径を変化させた種々の $\mathrm{Si}_{3} \mathrm{~N}_{4}$ セラミック スを各種ダイヤモンド砥石によりワンパス平面研削加工し た場合の比研削エネルギーや加工後の強度劣化を評価した 結果，以下のことが明らかとなった。

（1）砥石設定切込み量が小さく砥粒径が小さい場合, 材料の硬度の増大につれて比研削エネルギ一が増大する。

（2）砥粒径が大きいほぼ加工後の材料強度の低下は増 大し，各材料に打码強度低下は材料の機械的特性より求
められる遷移圧子半径が小さいほど大きい。

（3）平均砥粒切込み深さの増大につれて加工後の材料 強度は低下し，平均砥粒切込久深さの大きい領域での材料 強度は，材料の機械的特性から求められるき裂進展長さに 関する材料特性項が大きいほど低い值をとる.

謝 辞 本研究の実験及び考察に多大なるご協力を頂いた長 岡技術科学大学・実務訓練生（現在 : 同大学院生）の佐々木 勝 氏に深甚なる謝意を表します。

\section{文献}

1）右京良雄，和田重孝，J. Ceram. Soc. Japan，97，872-74 (1989).

2）三友 護, FC Report, 12, 310-13 (1994).

3) T. Nishioka, K. Matsunuma, T. Yamamoto, A. Yamakawa and M. Miyake, SAE Tech. Paper 920384 (1992).

4）海野邦昭，機械と工具，10月号，85-92（1990）

5) I. Inasaki and K. Nakayama, Ann. CIRP, Osaka, Vol. 35 (1986) pp. 211-14

6）宮原克敏，太田 稔，自動車技術会学術講演会前刷集, 921, 81-84 (1992).

7) K. Kitajima, G. Q. Cai, N. Kumagai, Y. Tanaka and H. W. Zheng, Ann. CIRP, Tokyo, Vol. 41 (1992) pp. 367-71.

8）松下健一，岡本 平，非破壊検查，35, 736-42 (1986).

9）西岡隆夫, 田中芳雄, 山川 晃, 三宅雅也, J. Ceram. Soc. Japan, 103, 335-39 (1995).

10）西岡隆夫, 田中芳雄, 山川 晃, 三宅雅也, J. Ceram. Soc. Japan, 102, 930-35 (1994).

11）田中芳雄，ニューセラミックス，No. 5, 37-44 (1988). 